Please cite as:

Giones, F., \& Miralles, F. (2015). Strategic Signaling in Dynamic Technology Markets: Lessons From Three IT Startups in Spain. Global Business and Organizational Excellence, 34(6), 42-50. doi:10.1002/joe.21634

\title{
Strategic Signaling in Dynamic Technology Markets: Lessons From Three IT
}

\author{
Startups in Spain
}

\author{
FERRAN GIONES AND FRANCESC MIRALLES
}

\section{Keywords}

Technology entrepreneurship, signaling theory, market signals, technology signals, social capital signals, opportunity exploration, opportunity exploitation

\begin{abstract}
Building a successful startup in the IT industry remains as an elusive dream for many technology-based entrepreneurs, the competitive dynamics of IT markets and the resource requirements for new entrants make it a rather uncertain strenuous effort.

In this article we describe how technology-based entrepreneurs strategically use signals to transform their ideas into viable businesses, regardless of their resource limitations and the complexity of the technology markets where they operate. We describe how entrepreneurs unlock the value proposition that makes a technology useful, observing the use of signals as market communication strategies. In this context, we look beyond the traditional value of the new firm's resources to explain the impact that entrepreneur's actions, as signals, introduce on the process of technology entrepreneurship in a startup. In this article, we use a multiple case study on three new technology-based firms to explore how their actions were interpreted as valuable market signals. The results suggest that entrepreneurs strategically use market, technology, and social capital signaling to mitigate uncertainty and advance in the technology entrepreneurship process. This research highlights the often unattended value of resources and actions as signaling elements; in particular it identifies that in highly
\end{abstract}




\section{Please cite as:}

Giones, F., \& Miralles, F. (2015). Strategic Signaling in Dynamic Technology Markets: Lessons From Three IT Startups in Spain. Global Business and Organizational Excellence, 34(6), 42-50. doi:10.1002/joe.21634

competitive and dynamic markets, understanding how to "signal" valuable information to stakeholders and market actors, could be as important as the actual technological development of the product or service of the new firm. Such findings are relevant for entrepreneurs and practitioners that can benefit from further understanding the impact of visible actions (that can be observed as signals) in the early stages of a new technology-based venture.

\section{Introduction}

Technology entrepreneurs are highly regarded as targets of economic policy (Lerner, 2010). The policy expectations on fostering technology-based entrepreneurs contrasts with our limited understanding on how technology entrepreneurship unfolds (Acs et al., 2011). As a result, we often find that initiatives that aim to spur high-growth technology-based entrepreneurial projects fail to achieve the expected results (Shane, 2009).

When we study what makes technology-based entrepreneurs different, our attention has mostly been on trying to decipher the resources configurations that would explain the success or failure of so many promising technologybased ventures. Alternatively, innovation management scholars have looked at more subtle elements such as the ability to adopt strategic orientations towards the market that could compensate for the initial technology-push orientation, with a demand-pull orientation (Brem \& Voigt, 2009); or in other words, to be able to combine the technology resources and potential with a disruptive value proposition (Finn, Søren, \& Stoyan, 2014) that is quickly accepted in the market.

In entrepreneurship research, we have traditionally adopted perspectives from strategic management such as the resources based view (RBV) to explain why some new firms were successful while others failed (Foss, Klein, Kor, \& Mahoney, 2008). Using the RBV perspective, we would expect to be able to explain successful new entrants in IT markets by identifying their unique combination of heterogeneous resources; for example, having the patent on a new design for integrated circuits and the financial support of an experienced Venture Capital firm. Instead, we find that firms endowed with technological and financial resources are not less likely to fail 


\section{Please cite as:}

Giones, F., \& Miralles, F. (2015). Strategic Signaling in Dynamic Technology Markets: Lessons From Three IT Startups in Spain. Global Business and Organizational Excellence, 34(6), 42-50. doi:10.1002/joe.21634

than those that start with more limited resource configurations, and that beyond initial resources configurations, there are additional elements that influence this process (Shepherd, Douglas, \& Shanley, 2000).

. The adoption of a strategic management perspective (RBV) that helps to understand how firm's resources are related to the capacity of the firm to compete and capture value in the market; provides more limited insights in contexts such as technology entrepreneurship, where actions, more than initial resources, are suggested to be critical in the value-creation that has to precede the value capture actions (Priem, Li, \& Carr, 2011)..

In this article, we use a multiple-case study approach to explore how three new technology-based firms in the IT Industry built signaling strategies to develop their entrepreneurial opportunity. First, we review the prior research on the technology entrepreneurship process and introduce the application of signaling theory in management to describe the value of entrepreneurial actions, regardless of the initial resources or characteristics of the firm. Next, we describe our methodology and the three cases we studied. Then, we present our results, especially our key finding: where there is an information asymmetry between the entrepreneur and the customers, the use of signals positively influences the opportunity exploration and exploitation activities. Finally, we discuss the results and highlight their implications..

\section{The Role of Action in the Technology Entrepreneurship Process}

This section starts with an overview of the technology entrepreneurship process, describing how the central processes in entrepreneurship: opportunity identification and exploration are influenced by the technological nature of the opportunity. It follows with the interpretation of entrepreneurial actions as signals, a perspective that offers additional information on how the technology entrepreneurship unfolds.

\section{Technology and the entrepreneurship process}




\section{Please cite as:}

Giones, F., \& Miralles, F. (2015). Strategic Signaling in Dynamic Technology Markets: Lessons From Three IT Startups in Spain. Global Business and Organizational Excellence, 34(6), 42-50. doi:10.1002/joe.21634

In a review of the different definitions given to technology entrepreneurship, Bailetti (2012) found that it typically is seen to involve: i) engineers or scientists operating small businesses; ii) finding an application for a technological advance; iii) a scientific and technical knowledge component; and iv) working with other actors to change technology. In proposing a new definition of technology entrepreneurship, Bailetti (2012) emphasizes value creation and capture: "Technology entrepreneurship is an investment in a project that assembles and deploys specialized individuals and heterogeneous assets that are intricately related to advances in scientific and technological knowledge for the purpose of creating and capturing value for a firm."

To describe how the technology entrepreneurship process unfolds, we reviewed prior literature that describes the main activities of the entrepreneurship process as: opportunity exploration (or identification) and opportunity exploitation (Shane \& Venkataraman, 2000). Although simplistic, this two-stage approach helps us to group the myriad of perspectives and definitions on the entrepreneurship process (Moroz \& Hindle, 2012), and gives sense to the idea of value creation first, and then value capture second. The idea of exploration and exploitation activities has been studied in management literature (Hill \& Birkinshaw, 2012), suggesting that organizations that are able to combine opportunity exploration (finding new opportunities) and exploitation (finding mechanisms to capture value), achieve an ambidexterity capacity that has positive impact on organizational performance (Barlatier \& Dupouët, 2015). Using those two main activitiesas a reference, how does the technological component affect the entrepreneurship process?

The technological component in the entrepreneurial opportunity is observed to introduce additional sources of uncertainty and complexity in the opportunity exploration; technology-based entrepreneurs are often seen to strongly rely on interactions with stakeholders and other external actors to make sense of the opportunity at hand (Giones, Zhou, Miralles, \& Katzy, 2013; Wood \& McKinley, 2010). To make progress in opportunity exploration, entrepreneurs need to act (McMullen \& Shepherd, 2006). Thus, regardless of the uncertainty and complexity, the technology-based entrepreneur is seen as an active innovator, aiming to put together the market 


\section{Please cite as:}

Giones, F., \& Miralles, F. (2015). Strategic Signaling in Dynamic Technology Markets: Lessons From Three IT Startups in Spain. Global Business and Organizational Excellence, 34(6), 42-50. doi:10.1002/joe.21634

application (or value proposition) with the technology-based product or service they are developing (Finn et al., 2014).

In this context, we argue that although prior knowledge on the technology and the market are valuable to identify and describe a technological opportunity (Shane, 2000), the value of this resource is reduced as the entrepreneur moves towards the opportunity exploitation. In this sense, the finding from Shane (2000) on how the entrepreneur's technology and/or market knowledge would influence the type of identified opportunity, does not imply that the entrepreneur also knows how to successfully exploit it. Furthermore, it has been suggested that entrepreneurs actually gain more from exchanging information with key customers, tailoring their new products and services to their emerging needs (Yli-Renko \& Janakiraman, 2008).

Advancing to the second stage, towards opportunity exploitation, we also find evidence of the specific characteristics of technology entrepreneurship. As happens with established organizations, the entrepreneur faces a situation that can be described as a tipical technology commercialization challenge. Nevertheless, when it comes to exploiting the opportunity, a startup is in a weaker position than established organizations because the technology, its application, and the newly assembled management team are untested (Shepherd et al., 2000). As a result, overcoming the uncertainty and caution of their potential customers becomes an additional challenge.

Despite the challenges and burdens, we still see technology-based firms emerging, creating new markets, and successfully competing with established players. Therefore, we are induced to look beyond the resources to further understand the technology entrepreneurship process.

\section{Signaling in the entrepreneurship process}

In order to see beyond the resource configuration of entrepreneurs, we propose to observe what they actually do with their resources and what actions do actually impact the market and their new venture performance (Priem et al., 2011). We build on the insights of Hsu \& Ziedonis (2013) to suggest that besides their direct function, 


\section{Please cite as:}

Giones, F., \& Miralles, F. (2015). Strategic Signaling in Dynamic Technology Markets: Lessons From Three IT Startups in Spain. Global Business and Organizational Excellence, 34(6), 42-50. doi:10.1002/joe.21634

resources and actions could also be used to generate signals to the market. In the early 70's Spence (1973) developed the signaling theory to explain how job applicants would disclose details that were interpreted as signals of their "qualities" to recruiters. This theory has seen more and more applications to explain actor behaviors in many management contexts (see Connelly et al., 2010).Our first step, is to understand that not all actions could convey information that impacts the potential market demand. Using a chess analogy, not every move carries information on the future intentions of that player, and not every move might be properly interpreted by the other player. Therefore, we are interested in understanding actions that can be interpreted as "quality" signals, that actually convey useful information to the market and stakeholders in general on the internal characteristics of the venture and its products (Connelly, Certo, Ireland, \& Reutzel, 2010).

Marketing is one of the main research streams that has used signaling theory (Kirmani \& Rao, 2000). In marketing research, it is suggested, for example, that information exchanges with stakeholders and potential customers are a necessary precedent to strike on the right actions (perceived as signals) in the definition of the "marketing mix". Closer to the context of technology entrepreneurship, it has been observed that, to reduce the observed information asymmetry between seller and the buyer, the entrepreneur can rely on signaling mechanisms, such as guarantee contracts, to reduce uncertainty and incentivize the first transactions (Godley, 2013). These insights from prior research fit well with the context we are describing: the more innovative the product, and the less known its producer (the entrepreneur), the stronger we expect the information asymmetry will be (Stiglitz, 1985).

We build on the assumption that new technology-based ventures, with no past transactions in the market, no track record of successful product development, and offering untested novel technology products, might have to rely on symbolic elements to convince their potential customers. In this sense, the capacity of the entrepreneur to act (and convey the right signals), regardless of the uncertainty and resource limitations, is expected to provide additional clues to understand the technology entrepreneurship process. 
Please cite as:

Giones, F., \& Miralles, F. (2015). Strategic Signaling in Dynamic Technology Markets: Lessons From Three IT Startups in Spain. Global Business and Organizational Excellence, 34(6), 42-50. doi:10.1002/joe.21634

\section{Methodology}

The limited understanding of the variables and their causal relationships on the technology entrepreneurship process suggested that we should adopt an exploratory approach. We selected case studies of organizations that would combine the different elements under study: a new venture with a novel technology product targeting a new market. We narrowed our focus on information technology ventures to isolate potential sources of variability related to different industrial contexts and product-service mix. An overview of the three cases is provided in Table 1. Note that all venture names have been replaced with pseudonyms to preserve confidentiality.

We combined different sources of data to build the cases, including in-depth interviews with the entrepreneurs, company presentations, and press releases. The primary source of data was the interviews (one per entrepreneurial venture) that were conducted between June 2010 and January 2011. Each interview lasted between 40 and 60 minutes, with follow-up questions. The interviews were transcribed and coded following theory-building procedures (Corbin \& Strauss, 1990).

Table 1. Descriptions of the new technology-based ventures under study

\begin{tabular}{llll}
\hline Venture Name & \multicolumn{1}{c}{ Product } & \multicolumn{1}{c}{$\begin{array}{c}\text { Descriptive Variables } \\
\text { Technology }\end{array}$} & \multicolumn{1}{c}{ Key Resources } \\
\hline DigiFasTV & $\begin{array}{l}\text { Value-added services to } \\
\text { digital television } \\
\text { broadcasters }\end{array}$ & $\begin{array}{l}\text { Software to broadcast digital television } \\
\text { and middleware for set-top boxes }\end{array}$ & $\begin{array}{l}\text { A strong network including } \\
\text { technology and institutional } \\
\text { partners }\end{array}$ \\
\hline EcoChip & Low-consumption circuits & $\begin{array}{l}\text { Designs for elastic clocks in integrated } \\
\text { circuits }\end{array}$ & $\begin{array}{l}\text { A leading international research } \\
\text { group on electronics }\end{array}$ \\
\hline RealSecurity & Software to prevent data & $\begin{array}{l}\text { SaaS solutions for data analysis using } \\
\text { new proprietary algorithms }\end{array}$ & $\begin{array}{l}\text { Prior knowledge of market and } \\
\text { technology and a strong software } \\
\text { development team }\end{array}$ \\
\hline
\end{tabular}

Following the interviews, we proceeded to write case stories for each venture (Eisenhardt, 1989). We designated the type of signals based on the asset or attribute that was being used to produce the signal. We expected the 
Please cite as:

Giones, F., \& Miralles, F. (2015). Strategic Signaling in Dynamic Technology Markets: Lessons From Three IT Startups in Spain. Global Business and Organizational Excellence, 34(6), 42-50. doi:10.1002/joe.21634

signals to relate either to the market (i.e., brand, customers, success stories) or to the technology (i.e., patents, unique software or equipment, labs, research profile) In the data analysis process, we found it necessary to add social capital assets (i.e., connections, institutional endorsements, and partners). We labelled those assets in each venture as either low or high based on the descriptions provided by each entrepreneur (low or high).

\section{Results}

Using the general theoretical description of opportunity exploration and opportunity exploitation, we describe the data results in Table 2. The data collected shows that: i) there is evidence of information asymmetry between the entrepreneur, the market (i.e., potential customers), and stakeholders regarding the venture and the quality of its products; ii) there is an active engagement by the entrepreneur in the new venture to reduce the described information asymmetry; and iii) an entrepreneur's behavior can be depicted as a strategic use of signaling to advance their opportunity-identification and exploitation activities.

Table 2. Signals and related actions of the new technology-based ventures under study

\begin{tabular}{lll}
\hline \multirow{2}{*}{ Venture } & \multicolumn{1}{c}{ Signals and Related Actions in the Technology Entrepreneurship Process } \\
\cline { 2 - 3 } DigiFasTV & \multicolumn{1}{c}{ Opportunity Exploration } & \multicolumn{1}{c}{ Opportunity Exploitation } \\
& Networking and patenting actions & $\begin{array}{l}\text { Market and social capital signals: } \\
\text { Brand building and pilot experiment actions }\end{array}$ \\
\hline EcoChip & $\begin{array}{l}\text { Technology signals: } \\
\text { Patenting and R\&D progress actions }\end{array}$ & $\begin{array}{l}\text { Social capital and technology signals: } \\
\text { Venture capital endorsement and R\&D } \\
\text { progress actions }\end{array}$ \\
\hline RealSecurity & $\begin{array}{l}\text { Market and technology signals: } \\
\text { Brand building and promotion of } \\
\text { technology updates actions }\end{array}$ & $\begin{array}{l}\text { Social capital and market signals: } \\
\text { Networking and beta customer actions }\end{array}$ \\
\hline
\end{tabular}

\section{Evidence of information asymmetry}

Although the technology-based entrepreneurs were rather clear on the benefits of their products, they found it difficult to convey this information to the customer, as described by the founder of RealSecurity, who 


\section{Please cite as:}

Giones, F., \& Miralles, F. (2015). Strategic Signaling in Dynamic Technology Markets: Lessons From Three IT Startups in Spain. Global Business and Organizational Excellence, 34(6), 42-50. doi:10.1002/joe.21634

characterized reactions of their potential customers as follows: "You are nobody, you don't have a brand, (therefore) we cannot work with you". Furthermore, this information asymmetry challenge is also observed with other stakeholders. In the words of EcoChip's founder, "The investors have no understanding of what our technology is and what we are doing", exposing that, reluctantly, "we have to prepare messages related to the market benefits of our technology", otherwise potential investors would not understand their technology solution.

In this sense, the founders of both EcoChip and DigiFasTV would argue that customers demanded additional guarantees that the product will be ready and working: they were asked to "show to third parties that the product was really ready to be used commercially", as described by DigiFasTV's founder.

\section{Types of signals in the technology entrepreneurship process}

Three different types of signals were perceived as valuable by the entrepreneurs: market, technology, and social capital signals.

First, the market signals included actions that were related to raising awareness of the new venture and its reputation. In the words of RealSecurity's founder: "We go to as many events in our industry as we can; it's exhausting, but we have to do it, and we write regularly in the security and communications magazine - a very technical magazine that everyone reads". Representatives of DigiFasTV would attend industry tradeshows even though they still had not completed their first version of the product. Thus, investments in brand development were seen as a valuable signal to their market, despite providing no short-term revenue.

Second, the technology signals were built upon unique technological resource of the new venture; in the case of EcoChip and DigiFasTV the resource was patents. The use of patents as signals would contribute to a market differentiation strategy. As described by DigiFasTV's founder, patents are "the elements that help the market to discern you from the others". Nevertheless, entrepreneurs would still struggle to convey this information to 


\section{Please cite as:}

Giones, F., \& Miralles, F. (2015). Strategic Signaling in Dynamic Technology Markets: Lessons From Three IT Startups in Spain. Global Business and Organizational Excellence, 34(6), 42-50. doi:10.1002/joe.21634

investors: "The biggest challenge has been to communicate our product - its benefits, and why it would be successful - to the interested investors", as described by DigiFasTV's founder.

Last, the social capital signals would include endorsements by institutions (public or private), the development and research partners, and even connections with well-known investors. Social capital signals were observed to be used to influence both access to resources and market activation. For example, EcoChip founder described the value of highlighting ties with venture capitalists: "Investors evaluate their decision based on whether there is another investor with a good reputation in the business". In a more explicit manner, DigiFasTV's founder mentioned that being part of an incubation program of an engineering university "worked as a public certification that we had the technological and financial resources to complete our technological development”.

\section{Signaling strategies to reduce uncertainty}

The entrepreneurs' use of different signal types at different moments suggests the potential strategic use of signaling in the entrepreneurship process. In the opportunity exploration activities, we observed that market signals were useful to increase the legitimacy and credibility of the venture; technology signals were used as credentials to access funding resources to sustain the exploration activities; and social capital signals was used to gain access to relevant contacts and to demonstrate legitimacy with institutions.

In the activities related to opportunity exploitation, our cases showed that market signals were used to accelerate first sales, making visible the confidence of the entrepreneur in the long-term quality of its products and services. Technology signals were seen to have a limited effect on sales, but still would be related to an indirect effect on raising the profile of the venture and its ability to stay in the market in the long run. Last, social capital signals were mostly seen in relation to raising the team's legitimacy and demonstrating their performance record. For example, RealSecurity would use the team members' credentials and endorsements to signal the quality of their team. 


\section{Please cite as:}

Giones, F., \& Miralles, F. (2015). Strategic Signaling in Dynamic Technology Markets: Lessons From Three IT Startups in Spain. Global Business and Organizational Excellence, 34(6), 42-50. doi:10.1002/joe.21634

\section{Discussion and Implications}

The findings of this research are in agreement with innovation literature on complex new product development and commercialization (Gans \& Stern, 2003). From the perspectives of marketing and signaling theory, the finding that entrepreneurs are seen to use multiple types of signals - strategically selecting what type of content to communicate - opens a potential area of research on the use of signal portfolios (Connelly et al., 2010). Furthermore, the insight that there could be a rational evaluation on the activation of certain signals in relation with some entrepreneurial activities has parallelisms with the strategic-choice literature in relation to entrepreneurship (Ozcan et al., 2009). It also brings further evidence on the often unexpected value of intellectual property in this type of settings (Smith, 2013).

The study is not absent of limitations: there is a need for additional evidence and measures for the signals, for example using a larger sample with a quantitative approach. The sample we used is biased, given that we relied on success stories of entrepreneurs. It would have been interesting to add cases of ventures that failed, and see whether their signaling strategy was related to their failure. In addition, further work is needed to derive objective measures of signals and to enrich the entrepreneur's perspective with views from the market and other relevant stakeholders in the technology entrepreneurship process.

This research contributes to the open call for further integration of the marketing and entrepreneurship literature (Webb, Ireland, Hitt, Kistruck, \& Tihanyi, 2010). Our findings suggest that market actions such as investments in advertising and brand-building efforts could contribute to legitimacy in exploration activities and accelerate sales in opportunity exploitation activities.

The findings are also valuable for entrepreneurs and agents involved in entrepreneurship promotion. On the one hand, we found evidence of the positive impact of engaging with the market, either to refine the entrepreneurial opportunity or to activate the market demand for the new products and services. On the other hand, we found 


\section{Please cite as:}

Giones, F., \& Miralles, F. (2015). Strategic Signaling in Dynamic Technology Markets: Lessons From Three IT Startups in Spain. Global Business and Organizational Excellence, 34(6), 42-50. doi:10.1002/joe.21634

useful insights regarding the communication strategies that technology-based entrepreneurs can use to shape the expectations of the market and mitigate the risks perceived by their potential buyers or stakeholders. Finally, the findings suggest that investors in technology-based firms should also consider the capacity of the entrepreneur to understand and signal to the market when assessing the potential of a new venture.

\section{Conclusion}

The results of the study suggest that new technology-based firms, immersed as they are in the challenge of finding an application for their promising technology, face an information asymmetry with the market. Regardless of the personal reputation and background of the entrepreneur, customers are reluctant to consider a new and untested product from an unknown new venture.

To overcome this situation, we observed that technology-based entrepreneurs rely on their opportunity exploration and exploitation actions, which issue signals to their potential customers and stakeholders. For example, producing market signals (i.e., conveying information on the quality and function of a product), technology signals (i.e., giving visibility to patents and superior technology features), and social capital signals (i.e., gaining public endorsements and displaying institutional ties) were seen to positively affect the transformation of the initial idea into a viable business.

This research holds implications for entrepreneurship researchers interested in extending the current resourceview to study the actions of entrepreneurs in technology-intense settings. It also has implications for entrepreneurs that aim to find alternative strategies to the technology-push and activate market demand for their products.

\section{About the Authors}




\section{Please cite as:}

Giones, F., \& Miralles, F. (2015). Strategic Signaling in Dynamic Technology Markets: Lessons From Three IT Startups in Spain. Global Business and Organizational Excellence, 34(6), 42-50. doi:10.1002/joe.21634

Ferran Giones is a Research Assistant at La Salle Innova Institute - Ramon Llull University in Barcelona, Spain. He has Bachelors and Master's degree in Business Administration from ESADE Business School in Barcelona. Ferran's professional background is in management consulting and international business-operations development. His academic research is in the areas of entrepreneurship and innovation, studying how entrepreneurs' ventures emerge in dynamic environments.

Francesc Miralles is the Dean of La Salle Campus Barcelona - Ramon Llull University (La Salle - URL) in Barcelona, Spain. He is also Professor of Information Systems, Innovation Management, and Research Methods. He has a PhD from the Polytechnic University of Catalonia (UPC) in Barcelona and an MBA from ESADE, also in Barcelona. Before joining La Salle - URL, he was Executive Director of the Information Society Observatory of Catalonia (FOBSIC), and Professor and Dean at the University Pompeu Fabra Barcelona. He has also held management positions in several organizations. His current research interests are in the area of information technologies management, innovation management, and entrepreneurship

\section{Acknowledgements}

An earlier version of this article was presented at the International Conference on Engineering, Technology, and Innovation (ICE), which was held from June 23rd to 25th in Bergamo, Italy. The ICE conference discusses systems engineering as a socio-technical task, with a focus on design of products and services, and the entrepreneurial innovation process for its adoption in society and the economy.

\section{References}

Acs, Z. J., Audretsch, D. B., Braunerhjelm, P., \& Carlsson, B. (2011). Growth and entrepreneurship. Small Business Economics, 39(2), 289-300. doi:10.1007/s11187-010-9307-2

Bailetti, T. (2012). Technology Entrepreneurship : Overview, Definition, and Distinctive Aspects. Technology Innovation Management Review, (February), 5-12. 
Working paper - full version at http://onlinelibrary.wiley.com/doi/10.1002/joe.21634/full

Please cite as:

Giones, F., \& Miralles, F. (2015). Strategic Signaling in Dynamic Technology Markets: Lessons From Three IT Startups in Spain. Global Business and Organizational Excellence, 34(6), 42-50. doi:10.1002/joe.21634

Barlatier, P.-J., \& Dupouët, O. (2015). Achieving Contextual Ambidexterity With Communities of Practice at GDF SUEZ. Global Business and Organizational Excellence, 34(3), 43-53. doi:10.1002/joe.21603

Brem, A., \& Voigt, K.-I. (2009). Integration of market pull and technology push in the corporate front end and innovation management-Insights from the German software industry. Technovation, 29(5), 351-367. doi:10.1016/j.technovation.2008.06.003

Connelly, B. L., Certo, S. T., Ireland, R. D., \& Reutzel, C. R. (2010). Signaling Theory: A Review and Assessment. Journal of Management, 37(1), 39-67. doi:10.1177/0149206310388419

Finn, H., Søren, J., \& Stoyan, T. (2014). Disruptive Innovation vs Disruptive Technology: The Disruptive Potential of the Value Propositions of 3D Printing Technology Startups. Technology Innovation Management Review, (December).

Foss, N. J., Klein, P. G., Kor, Y. Y., \& Mahoney, J. T. (2008). Entrepreneurship, subjectivism, and the resource-based view: toward a new synthesis. Strategic Entrepreneurship Journal, 2(1), 73-94. doi:10.1002/sej.41

Gans, J. S., \& Stern, S. (2003). The product market and the market for "ideas": commercialization strategies for technology entrepreneurs. Research Policy, 32(2), 333-350. doi:10.1016/S0048-7333(02)00103-8

Giones, F., Zhou, Z., Miralles, F., \& Katzy, B. (2013). From Ideas to Opportunities: Exploring the Construction of Technology-Based Entrepreneurial Opportunities. Technology Innovation Management Review, (June), 13-20.

Godley, A. C. (2013). Entrepreneurial opportunities, implicit contracts, and market making for complex consumer goods. Strategic Entrepreneurship Journal, 7(4), 273-287. doi:10.1002/sej.1167

Hill, S. a., \& Birkinshaw, J. (2012). Ambidexterity and Survival in Corporate Venture Units. Journal of Management, (May 2012). doi:10.1177/0149206312445925

Hsu, D. H., \& Ziedonis, R. H. (2013). Resources as dual sources of advantage: Implications for valuing entrepreneurial-firm patents. Strategic Management Journal, 34(7), 761-781. doi:10.1002/smj.2037

Kirmani, A., \& Rao, A. R. (2000). No Pain, No Gain: A Critical Review of the Literature on Signaling Unobservable Product Quality. Journal of Marketing, 64(2), 66-79. doi:10.1509/jmkg.64.2.66.18000

Lerner, J. (2010). The future of public efforts to boost entrepreneurship and venture capital. Small Business Economics, 35(3), 255264. doi:10.1007/s11187-010-9298-z

McMullen, J. S., \& Shepherd, D. A. (2006). Entrepreneurial Action and the Role of Uncertainty in the Theory of the Entrepreneur. Academy of Management Review, 31(1), 132-152. doi:10.5465/AMR.2006.19379628

Moroz, P. W., \& Hindle, K. (2012). Entrepreneurship as a Process: Toward Harmonizing Multiple Perspectives. Entrepreneurship Theory and Practice, 36(4), 781-818. doi:10.1111/j.1540-6520.2011.00452.x

Ozcan, P., Eisenhardt, K. M., Cox, E., Davis, J., Greenstein, S., Hillman, A., ... Ocasio, W. (2009). Origin of Alliance Portfolios: Entrepreneurs, Network Strategies, and Firm Performance. Academy of Management Journal, 52(2), $246-279$. doi:10.5465/AMJ.2009.37308021

Priem, R. L., Li, S., \& Carr, J. C. (2011). Insights and New Directions from Demand-Side Approaches to Technology Innovation, Entrepreneurship, and Strategic Management Research. Journal of Management, 38(1), 346-374. doi:10.1177/0149206311429614 
Working paper - full version at http://onlinelibrary.wiley.com/doi/10.1002/joe.21634/full

Please cite as:

Giones, F., \& Miralles, F. (2015). Strategic Signaling in Dynamic Technology Markets: Lessons From Three IT Startups in Spain. Global Business and Organizational Excellence, 34(6), 42-50. doi:10.1002/joe.21634

Shane, S. A. (2000). Prior knowledge and the discovery of entrepreneurial opportunities. Organization Science, $25(1), 448-469$.

Shane, S. A. (2009). Why encouraging more people to become entrepreneurs is bad public policy. Small Business Economics, 33(2), 141-149. doi:10.1007/s11187-009-9215-5

Shane, S. A., \& Venkataraman, S. (2000). The Promise of Entrepreneurship as a Field of Research. Academy of Management Review, 25(1), 217-226. doi:10.5465/AMR.2000.2791611

Shepherd, D. A., Douglas, E. J., \& Shanley, M. (2000). New venture survival. Journal of Business Venturing, 15(5-6), 393-410. doi:10.1016/S0883-9026(98)00032-9

Smith, D. (2013). Leveraging Old Intellectual Property to Accelerate Technology Entrepreneurship. Technology Innovation Management Review, (June).

Spence, M. (1973). Job Market Signaling. Quarterly Journal of Economics, 87(3), 355-374. doi:http://www.jstor.org/stable/1882010

Stiglitz, J. E. (1985). Information and Economic Analysis: A Perspective. The Economic Journal, 95(Supplement Conference Papers), 2141. doi:http://www.jstor.org/stable/2232867

Webb, J. W., Ireland, R. D., Hitt, M. a., Kistruck, G. M., \& Tihanyi, L. (2010). Where is the opportunity without the customer? An integration of marketing activities, the entrepreneurship process, and institutional theory. Journal of the Academy of Marketing Science, 39(4), 537-554. doi:10.1007/s11747-010-0237-y

Wood, M. S., \& McKinley, W. (2010). The production of entrepreneurial opportunity: a constructivist perspective. Strategic Entrepreneurship Journal, 4(1), 66-84. doi:10.1002/sej.83

Yli-Renko, H., \& Janakiraman, R. (2008). How customer portfolio affects new product development in technology-based entrepreneurial firms. Journal of Marketing, 72(September), 131-148. 